\title{
SISTEM INFORMASI PENCATATAN DAN LAPORAN PADA BIDAN PRAKTEK SWASTA (BPS) "FITRI ALATIF" BERBASIS DEKSTOP
}

\author{
Ahmad Jaya ${ }^{1^{*}}$, Rodianto $^{2}$, Akbar $^{3}$ \\ Program Studi Teknik Informatika Fakultas Teknik, Universitas Teknologi Sumbawa \\ ${ }^{*}$ Corresponding Author email: \\ ahmad.jaya@uts.co.id, rodianto@uts.ac.id, cebaranaklangam@gmail.com
}

\begin{abstract}
Abstrak
Diterima

Bulan September 2019

Diterbitkan Bulan Oktober 2019

Keyword : Metode Prototype, Vb.Net, UML, MySql

Kualitas pelayanan kesehatan perlu ditingkatkan, baik dari segi sistem informasi BPS, Sistem Pencatatan, Sistem penunjang dan Sistem pendukung pelayanan kesehatan. Dalam sistem administrasi pelayanan kesehatan dapat dilakukan proses pendataan bagi pasien yang berkunjung dengan melakukan pencatatan yang meliputi aktivitas pasien. Dokumen yang berisi riwayat pasien yang berkunjung tersebut disebut BPS. Analisis kebutuhan data yang berkaitan dengan BPS. Perangkat lunak dibangun menggunakan bahasa pemprograman $M y S q l$, Vb.Net dan cristalreport. Adapun tujuan dari pembuatan aplikasi ini adalah untuk mengetahui sistem yang berjalan dalam proses pendataan pasien di BPS "Fitri Alatif" sebelum adanya rancangan suatu sistem informasi BPS "Fitri Alatif" yang terkomputerisasi, sehingga dapat dibangun suatu sistem informasi pencatatan dan laporan menggunakan metode prototype berbasis desktop pada Bidan Praktek Swasta serta menggunakan UML (Unified Modeling Lenguage) untuk pemodelan sistem. Dimana sistem ini dapat digunakan untuk mempermudah pihak manajemen BPS dalam pencatatan dan laporan pasien yang berkunjung dalam skala yang cukup besar.
\end{abstract}

\section{PENDAHULUAN}

Bidan Praktek Swasta (BPS), merupakan penyedia layanan kesehatan, yang memiliki kontribusi cukup besar dalam memberikan pelayanan, khususnya dalam meningkatkan kesejahteraan ibu dan anak. Masyarakat sebagai pengguna jasa layanan bidan memperoleh akses pelayanan yang bermutu, sehingga perlu adanya regulasi pelayanan praktek bidan secara jelas. Persiapan yang dilakukan sebelum bidan melaksanakan pelayanan praktek yaitu seperti perizinan, tempat praktek, ruangan, peralatan praktek, dan kelengkapan administrasi seluruhnya harus sesuai dengan standar yang diselenggarakan oleh lebih dari satu jenis tenaga kesehatan dan dipimpin oleh seorang tenaga medis.

Permasalahan yang sering terjadi didalam bidan praktek swasta (BPS) yaitu sistem yang digunakan masih dilakukan secara manual baik dalam proses pendaatan yang dilakukan dengan mencatat pada buku, sehingga terjadi penumpukan berkas, buku catatan sebagai acuan pembuatan laporan hilang serta terjadi kesalahan yang menyebabkan pencarian data harus membuka buku kembali. Proses pencatatan laporan juga sering kali tidak berdasarkan hasil pencatatan pada buku dan mengharuskan pihak administrasi untuk membuka berkas kembali untuk melakukan pencarian terhadap data pasien laporan harian baik mingguan maupun bulanan. Permasalahan tersebut juga dialami oleh pihak BPS "Fitri Alatif" ketika melakukan proses pencatatan dan pelaporan.

Berdasarkan masalah yang terjadi dibangun suatu Sistem Informasi Pencatatan dan Laporan pada BPS dengan menggunakan metode prototype berbasis Desktop. Sistem ini dapat digunakan untuk mempermudah pihak BPS dalam pencatatan dan pelaporan administrasi.Sehingga dapat menampung lebih banyak data tanpa harus menggunakan cara manual.

\section{LANDASAN TEORI}

\section{Bidan Praktek Swasta}

Bidan Praktek Swasta (BPS) merupakan pelayanan kesehatan dibidang kesehatan dasar. Praktek bidan adalah serangkaian kegiatan pelayanan kesehatan yang diberikan oleh bidan kepada (individu, keluarga, dan masyarakat) sesuai dengan kewenangan dan kemampuannya. Bidan yang menajalankan praktek pada saran kesehatan atau program (Anggoro, 2016:12).

\section{Sistem Informasi}

Sistem Informasi adalah suatu sistem di dalam suatu organisasi yang mempertemukan kebutuhan pengolahan transaksi harian, mendukung operasi, bersifat manejerial dan kegiatan strategi dari suatu organisasi dan menyediakan pihak luar tertentu 
dengan laporan-laporan yang diperlukan (Tata Sutabri, 2012:38)

\section{Visual Studio (VB.Net)}

Microsoft Visual Studio adalah sebuah Integrated Development Environment buatan Microsoft Corporation. Microsoft Visual Studio dapat digunakan untuk mengembangkan aplikasi dalam native code (dalam bentuk bahasa mesin yang berjalan di atas windows) ataupun managed code (dalam bentuk Microsoft Intermediate Language diatas .Net Framework). Selain itu, Visual Studio juga dapat digunakan untuk mengembangkan aplikasi Silverlight, aplikasi Windows Mobile (yang berjalan di atas .Net Compact Framework). Visual Basic mencakup sebuah kode editor yang didukung oleh fitur intellisense atau yang disebut dengan code refactoring (winarno,2010:8)

\section{Prototype}

Sebuah prototype adalah versi awal dari sistem perangkat lunak yang digunakan untuk mendemonstrasikan konsep-konsep, percobaan rancangan, dan menemukan lebih banyak masalah dan solusi yang memungkinkan sistem prototype memperbolehkan pengguna untuk mengetahui bagaimana sistem berjalan dengan baik. Penggunaan metode prototyping di dalam penelititan ini bertujuan agar peneliti mendapatkan gambaran apikasi yang akan dibangun melalui tahap pembangunan aplikasi prototype terlebih dahulu yang akan dievaluasi oleh user selanjutnya akan dijadikan acuan untuk membuat aplikasi yang dijadikan produk akhir sebagai output dari penelitian (Sommerville, 2011:1045).

\section{METODE PENELITIAN}

Metode yang digunakan dalam penelitian ini adalah Prototype yang terdiri dari 5 tahapan yaitu:

a. Mengidentifikasi kebutuhan

Pada tahap ini menjelaskan apa saja yang dibutuhkan dalam membangun perangkat lunak tersebut.

b. Membuat sebuah desain

Pada tahap ini penulis membuat sebuah desain, merupakan sebuah langkah untuk membuat sebuah sistem yang dimana sebuah sistem yang akan digunakan dalam membuat sebuah aplikasi berbasis desktop.

c. Penulisan kode program

Dalam tahapan ini penulis menerjemahkan sebuah desain sistem yang telah dibuat sebelumnya ke dalam bahasa pemrograman Visual Studio (Vb.net 2010) dan MySQL sebagai sistem manajemen basis data.

d. Pengujian Aplikasi
Tahapan pengujian program adalah tahapan sistem yang sudah dibuat akan dicoba. Tujuan dari pengujian ini adalah untuk menemukan apakah terdapat kerusakan (error) dalam sistem serta menguji kinerja sistem apakah sudah berjalan sesuai dengan yang diharapkan atau tidak.

e. Penerapan Aplikasi

Pada tahapan ini Setelah melakukan sebuah pengujian sistem yang telah dibuat akan mulai diterapkan pada Bidan Praktek Swasta (BPS). Penerapan dan pengoperasian sistem yang dibuat untuk menggantikan sistem yang sebelumnya menggunakan sistem manual dengan menggunakan buku menjadi sistem informasi komputerisasi yang dapat membantu mengelola data pasien yang mendaftar di (BPS).

\section{HASIL DAN PEMBAHASAN}

Dengan berdasarkan metode Prototype yang digunakan dalam penelitian ini, maka proses yang dilakukan dalam membangun Sistem Informasi Pencatatan dan Laporan Pada Bidan Praktek Swata (BPS) Berbasis Dekstop adalah sebagai berikut:

\section{Analisis Kebutuhan}

Dalam tahapan ini penelitian mendapatkan data dan informasi yang dibutuhkan. Teknik pengumpulan data merupakan langkah yang paling baik dalam penelitian, karena tujuan utama dari penelitian adalah mendapatkan data. Salah satunya adalah dengan melakukan wawancara, yang merupakan pertemuan dua orang dengan cara bertatap muka untuk mendapatkan informasi, sehingga dapat dikontruksikan makna dalam suatu topik tertentu. Dalam hal ini penelitian melakukan wawancara dengan pihak Bidan Praktek Swasta (BPS).Berikut adalah hasil analisis kebutuhan:

a. Kebutuhan Pengguna

Pengguna yang terlibat didalam sistem informasi yaitu bagaian administrasi dan penginputan data. Kebutuhan dari pengguna tersebut yaitu:

Tabel 1. Kebutuhan Pengguna

\begin{tabular}{|c|c|}
\hline Pengguna & Keterangan \\
\hline Admin & $\begin{array}{ll}- & \text { Mengubah data } \\
& \text { login } \\
\text { - } & \text { Menambah dan } \\
\text { menghapus data }\end{array}$ \\
\hline
\end{tabular}




\begin{tabular}{|l|l|}
\hline & \multicolumn{1}{|c|}{ pasien } \\
\hline Operator & $\begin{array}{l}\text { Melihat data registrasi pada } \\
\text { BPS }\end{array}$ \\
\hline Laporan & $\begin{array}{l}\text { Membuat laporan keuangan } \\
\text { dan laporan bulanan. }\end{array}$ \\
\hline
\end{tabular}

diagram yang terdiri dari suatu proses dan menggambarkan ruang lingkup dari secara umum dari sistem yang dibuat yaitu Sistem Informasi Pencatatan dan Laporan pada Bidan Praktek Swasta.

b. Kebutuhan Perangkat Keras

Perangkat keras yang akan digunakan untuk membuat sistem dan merancang sebuah sistem informasi Pencatatan dan Laporan BPS "Fitri Alatif' yaitu:

\section{Tabel 2. Kebutuhan Perangkat Keras}

\begin{tabular}{|c|c|}
\hline Nama Perangkat & Spesifikasi \\
\hline Notebook & $\begin{array}{c}\text { Installed Memory } \\
\text { (RAM) 2.00 }\end{array}$ \\
\cline { 2 - 2 } & $\begin{array}{c}\text { Processor AMD, HD } \\
\text { Graphics 1.00GHZ }\end{array}$ \\
\cline { 2 - 2 } & Hardisk 320 GB \\
\cline { 2 - 2 } & Bio, InsyedH 20 \\
& Version V1.08 \\
\cline { 2 - 2 } & Monitor, Generic PnP \\
& Monitor \\
\hline
\end{tabular}

c. Kebutuhan Perangkat Lunak

Kebutuhan perangkat lunak yang digunakan untuk sistem informasi permintaan kantong ini adalah:

Tabel 3. Kebutuhan Perangkat Lunak

\begin{tabular}{|c|c|}
\hline Perangkat Lunak & Keterangan \\
\hline Windows 7 Ultimate & \\
\hline XAMPP & XAMPP Versi 1.7.7 \\
\hline MySQL & MySQL versi 5.6.20 \\
\hline Visual Studio 2010 & $\begin{array}{c}\text { VB.Net 2010 } \\
\text { Ultimate }\end{array}$ \\
\hline MySQL ODBC 5.2 & ODBC 5.2 \\
\hline
\end{tabular}

\section{Rancangan Sistem}

Dalam proses perancangan system ini bertujuan untuk memberikan gambaran tentang sistem yang akan dibuat dan tampilan dari sistem. Tahap ini membantu peneliti dalam mendefinisikan gambaran sistem secara keseluruhan.

3. Use case Diagaram

Use case diagram merupakan sebuah teknik yang digunakan dalam pengembangan sebuah software atau sistem informasi untuk menangkap kebutuhan fungsional dari sistem yang bersangkutan use case menjelaskan interaksi yang terjadi dimana actor berintraksi dengan sistem.

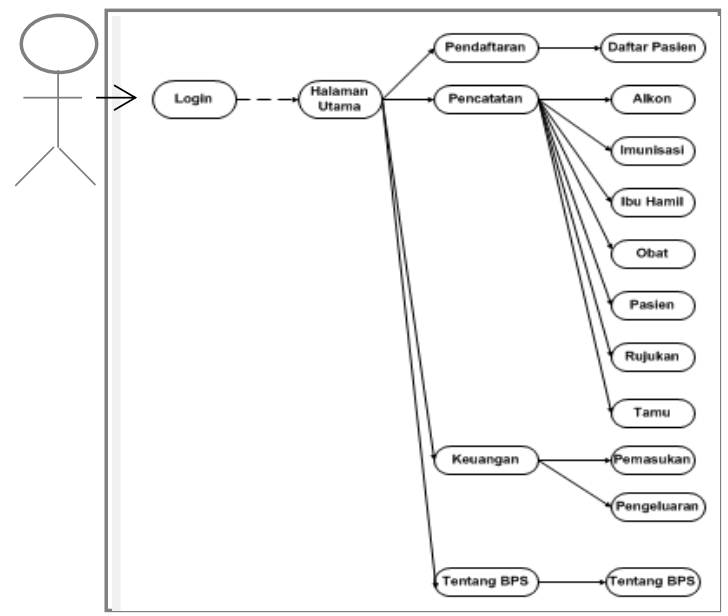

Gambar 1. Use case Diagram

Pada Use Case Diagram diatas sistem memberikan akses kepada admin untuk mengelola data yang didalamnya terdapat data pendaftaran, pencatatan, keuangan, laporan, pembayaran dan tentang BPS.

\section{Activity Diagram}

Activity Diagram merupakan salah satu cara pemodelan proses yang dilakukan didalam suatu Use Case Diagram. Berikut Activity Diagram Sistem Informasi Pencatatan dan Laporan BPS. Activity Diagram adalah yang menggambarkan tentang aktifitas yang terjadi pada sistem. Dari pertama sampai akhir diagram ini menunjukan langkah-langkah dalam proses kerja sistem yang kita buat. Contohnya langkah-langkah memasak air. Tetapi kita menjelaskan dengan bentuk grafik. Struktur diagram ini juga mirip dengan flowchart.

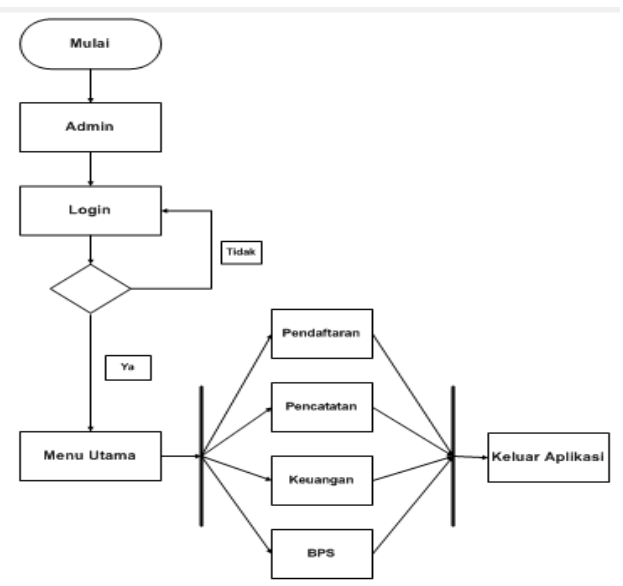


Gambar 2. Activity Diagram Sistem Informasi Pencatatan dan Laporan

Berdasarkan Activity Diagram diatas dimulai dari admin yang melakukan password dan username berhasil maka muncul menu utama yang menampilkan menu pendaftaran, pencatatan, keuangan, laporan, pembayaran dan tentang Bidan Praktek Swasta (BPS) dari sistem. Ketika admin tidak dapat berhasil melakukan login maka admin diminta untuk melakukan login ulang.

\section{Activity Diagram Pendaftaran}

Adapun tahapan activity diagram Pendataran dibawah ini adalah sebagai berikut:

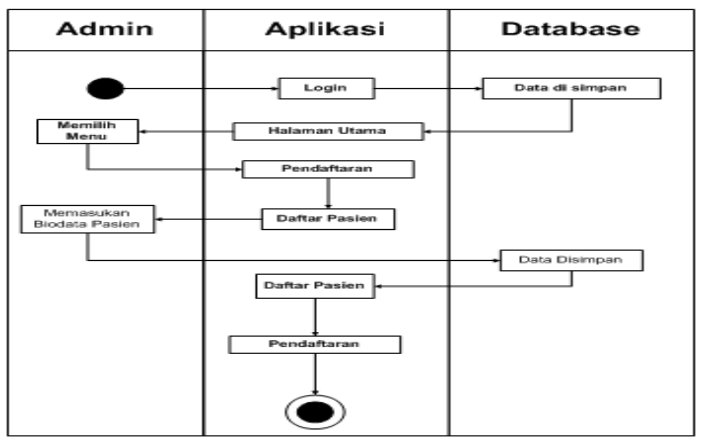

Gambar 3. Activity Diagram Pendaftaran

Pada proses activity diatas admin melakukan login dri aplikasi menampilkan login maka admin diminta untuk memasukan username dan password jika password benar maka akan diproses oleh database dan masuk ke aplikasi, jika salah maka akan muncul pemberitahuan bahwa password yang anda masukan salah. Jika sudah masuk ke aplikasi admin memilih menu pendaftaran, setalah itu aplikasi menampilkan menu daftar maka admin menambahkan data pasien, setelah itu data akan tersimpan ke dalam databases dan akan kembali ke aplikasi.

\section{Sequence Diagram}

Sequence Diagram merupakan diagram yang menggambarkan suatu interaksi antar objek . Berikut Sequence diagram pada sistem informasi pencatatan dan laporan pada BPS:

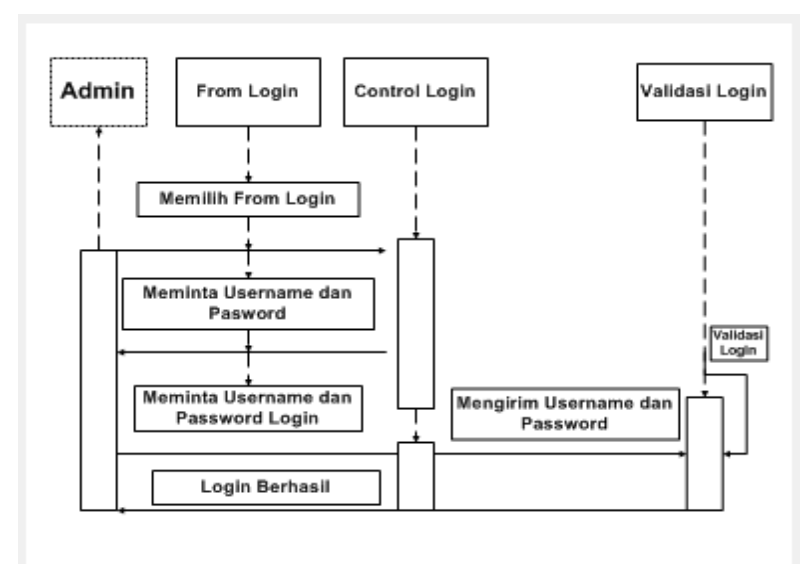

Gambar 4. Sequence Diagram

Proses yang terjadi didalam diagram tersebut adalah ketika admin ingin masuk ke menu utama terjadi proses login yang mengharuskan untuk memasukan username dan password, ketika username dan password sudah dimasukan maka terjadi sebuah proses pengiriman username dan password kedalam tabel login, setelah terjadi proses validasi yaitu username dan password sesuai maka login berhasil dan akan masuk ke menu utama.

\section{Class Diagram}

Class diagram digunakan untuk menampilkan beberapa kelas yang ada didalam sistem perangkat lunak yang akan dikembangkan. Class diagram membuktikan bahwa relasi antara class dalam sistem yang sedang dibangun dan bagaimana mereka saling terkait untuk menggapai suatu tujuan. Berikut adalah diagram class diagram dari sistem informasi BPS. 


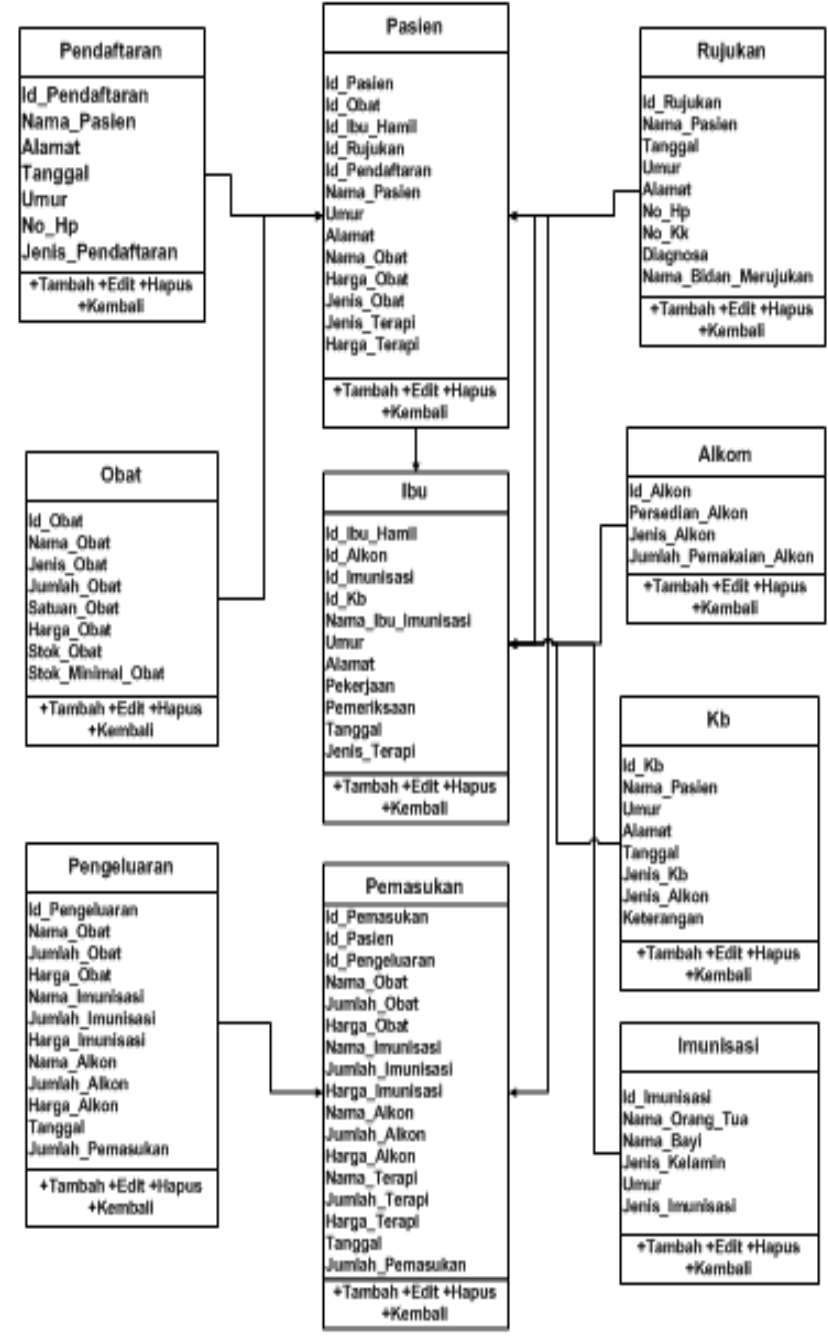

Gambar 5. Class Diagram Rancangan Struktur Database.

Adapun rancangan database dari sistem informasi BPS adalah sebagai berikut:

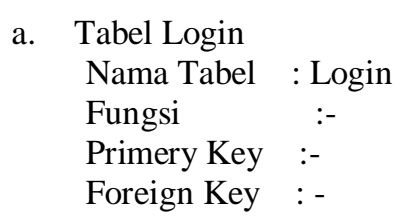

Tabel 6. Tabel Login

\begin{tabular}{|c|c|c|c|}
\hline Nama Data & Tipe Data & Size & Keterangan \\
\hline User Name & Varchar & 15 & Id Admin \\
\hline Password & Varchar & 15 & $\begin{array}{c}\text { Id Password } \\
\text { Admin }\end{array}$ \\
\hline
\end{tabular}

b. Tabel Alkom

$\begin{array}{ll}\text { Nama Tabel } & \text { : Alkon } \\ \text { Fungsi } & :- \\ \text { Primery Key } & : \text { id_Alkon } \\ \text { Foreign } & :-\end{array}$

Tabel 7. Alkon

\begin{tabular}{|l|l|l|l|}
\hline $\begin{array}{l}\text { Nama } \\
\text { Data }\end{array}$ & Tipe Data & Size & Keterangan \\
\hline Id_Alkon & Varchar & 30 & $\begin{array}{l}\text { Berisi id } \\
\text { alkon }\end{array}$ \\
\hline $\begin{array}{l}\text { Persediaan } \\
\text { _Alkon }\end{array}$ & Int & 11 & $\begin{array}{l}\text { Berisi } \\
\text { persediaan } \\
\text { alkon }\end{array}$ \\
\hline $\begin{array}{l}\text { Jenis_Alk } \\
\text { om }\end{array}$ & Text & 100 & Berisi IUD \\
\hline $\begin{array}{l}\text { Jumlah_Pe } \\
\text { makaian_ } \\
\text { Alkon }\end{array}$ & Int & 11 & $\begin{array}{l}\text { Jumlah } \\
\text { pemakaian }\end{array}$ \\
\hline
\end{tabular}

\section{Rancangan Tampilan}

Adapun rancangan tampilan interface dari sistem informasi BPS (Bidan Praktek Swasta) ini adalah sebagai berikut :

1. Tampilan Menu Login Adapun Tampilan Login adalah sebagai berikut:

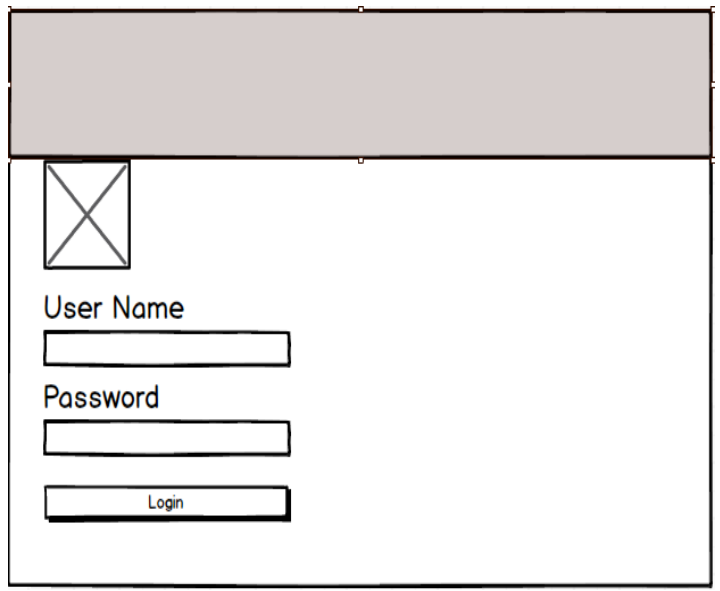

Gambar. 6 Menu Login Sebelum Revisi

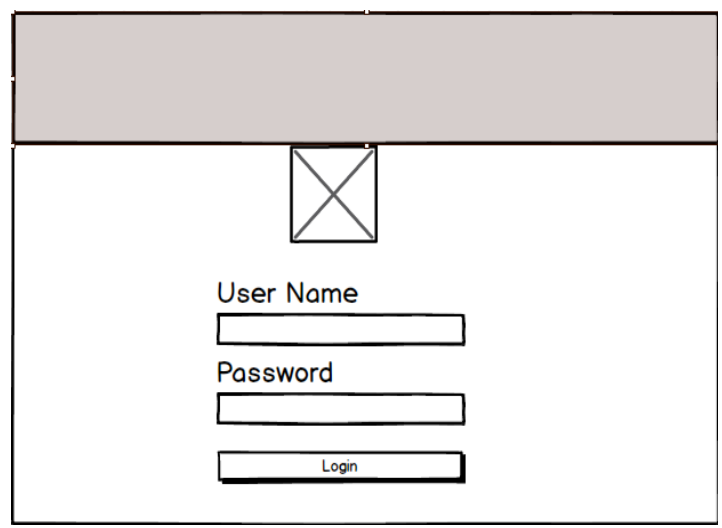

Gambar 7. Menu Login 
Menu Login adalah yang digunakan admin untuk masuk ke dalam sistem informasi pencatatan dan laporan pada BPS terdapat dua kolom untuk memasukan user id dari admin serta untuk password. Dan terdapat satu buah button berfungsi sebagai untuk masuk kedalam sistem.

1. Tampilan Menu Utama

Adapun tampilan menu utama adalah sebagai berikut:

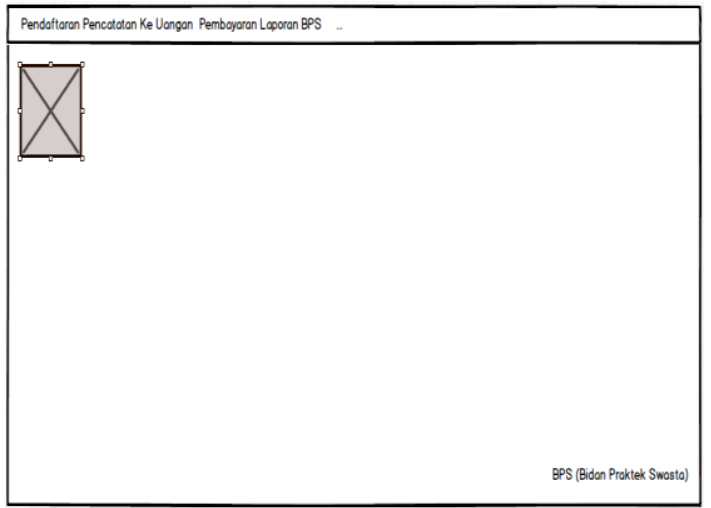

Gambar 8. Tampilan Menu Utama Sebelum Revisi

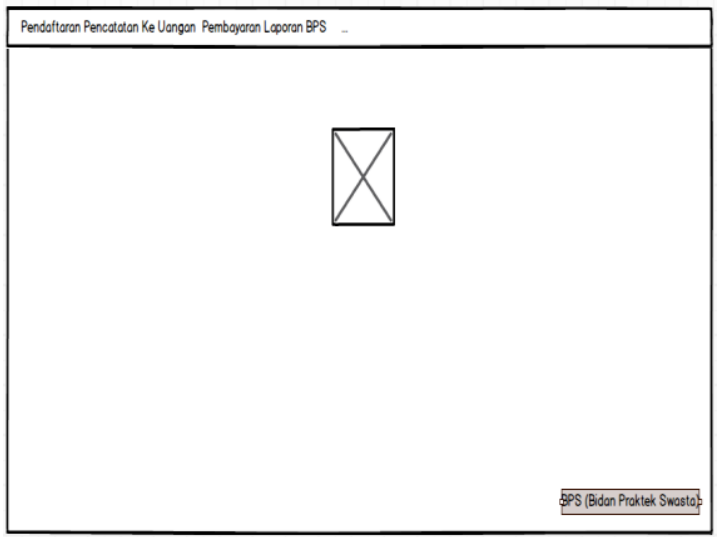

Gambar 9. Menu Utama

Menu utama adalah menu yang menjadi tampilan utama dari sistem informasi pencatatan dan laporan pada BPS yang berisi menu data pasien, pendaftaran, pencatatan, keuangan, pembayaran, laporan, BPS dan menu keluar ketika ingin keluar dari aplikasi.

2. Tampilan Menu Pendaftaran

Adapun tampilan menu pendaftaran adalah sebagai berikut:

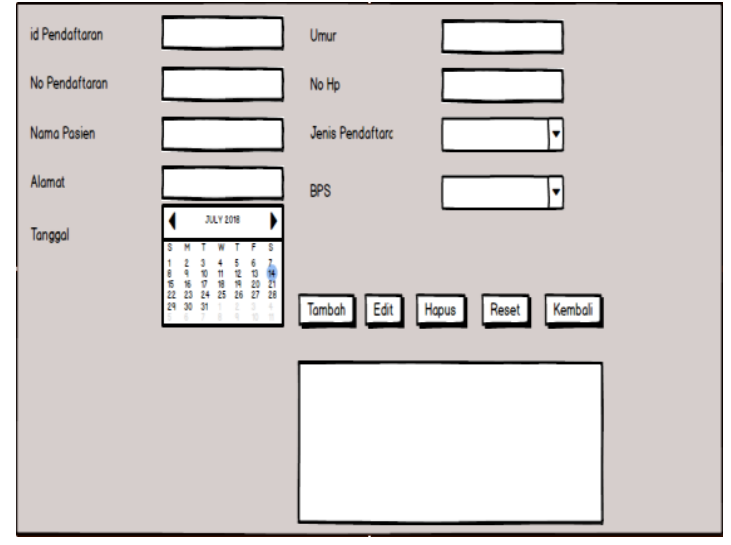

Gambar 10. Tampilan Menu Pendaftaran

Menu pendaftaran menjadi sub-menu dari menu pendaftaran. Menu ini digunakan untuk pasien yang mendaftarkan diri di BPS. Dengan adanya tombol button tambah maka pasien dinyatakan telah terdaftar di BPS. Button edit digunakan jika terjadi kesalahan dalam penginputan biodata pasien. Button hapus digunakan untuk menghapus biodata pasien yang sudah kadaluarsa. Button reset digunakan untuk mengulang isi biodata pasien yang sudah terdaftar. Button kembali digunakan untuk kembali ke menu utama.

3. Tampilan Menu Obat Adapun tampilan menu data obat adalah sebagai berikut:

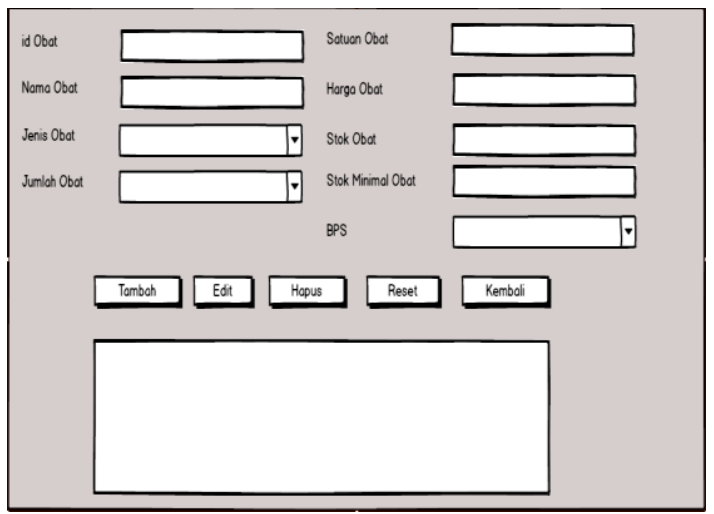

Gambar 11. Tampilan Menu Obat

Menu data obat menjadi sub-menu dari menu pencatatan, menu ini digunakan untuk penginputan data obat. Button tambah digunakan untuk menambah data obat. Button edit digunakan untuk melakukan perubahan data obat yang sudah dimasukan oleh admin kedalam sistem. Button hapus digunakan untuk menghapus data yang sudah dimasukan oleh admin kedalam sistem. Button reset digunakan untuk admin mengisi kembali data obat. Button kembali digunakan untuk kembali ke menu utama. 


\section{Implementasi Program}

Setelah melakukan perancangan sistem BPS (Bidan Praktek Swasta) dengan menggunakan balsamiq mockup, langkah selanjutnya adalah membuat antar muka sistem yang merupakan langkah untuk membangun intraksi anatar sistem dan admin dengan secara baik.

Adapun tampilan dari sistem adalah sebagai berikut:

a. Tampilan Menu Login

Pada menu ini admin diminta untuk memasukan username dan Password, apabila dari proses login berhasil maka aplikasi akan menampilkan menu selanjutnya yaitu menu utama, jika menu login tidak berhasil maka admin diminta agara memasukan username dan password kembali dan aplikasi dapat dilanjutkan ke menu utama.

Adapun tampilan login dari sistem BPS adalah sebagai berikut:

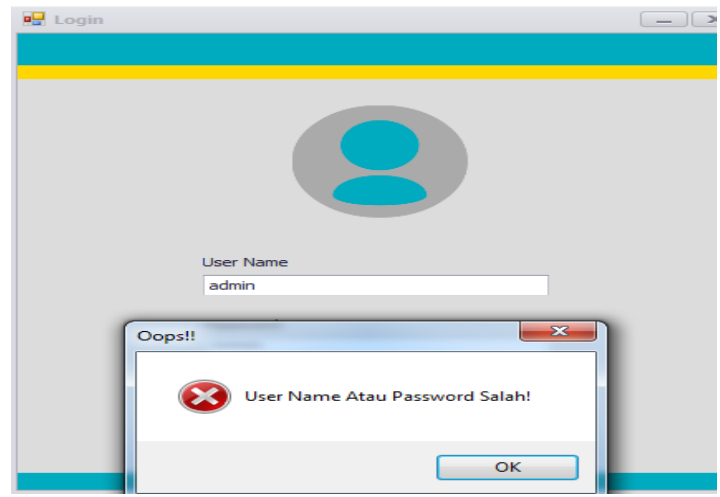

\section{Gambar 12. Tampilan Menu Login gagal}

Adapun tampilan menu login berhasil adalah sebagai berikut:

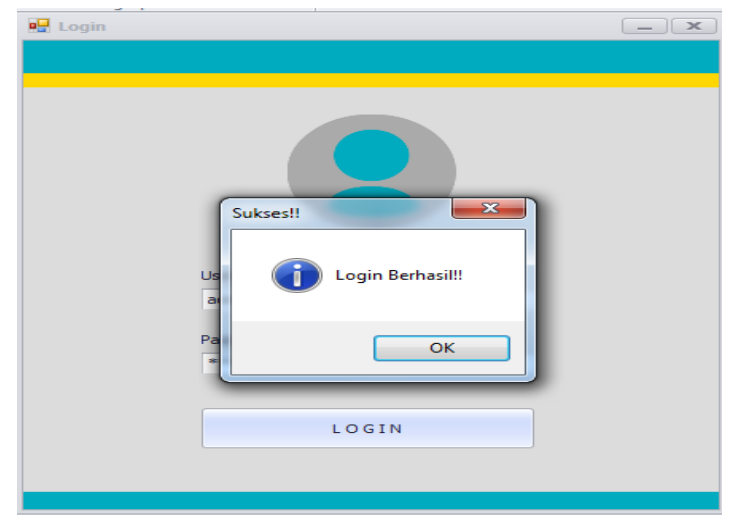

Gambar 13. Tampilan Menu Login Berhasil
2. Tampilan Menu Utama

Setelah login admin mendapatkan akses dari sistem BPS ssetelah itu maka akan muncul tampilan menu utama. Didalam sistem yang beroprasi menu dan sub-menu yang digunakan untuk mengakses sistem informasi Bidan Praktek Swasta (BPS) seperti $s u b$-menu pendaftaran, pencatatan, keuangan, pembayaran, laporan dan menu tentang Bidan Praktek Swasta. Menu utama ini digunakan untuk memanggil menu lainnya karena merupakan tampilan induk dari sistem dan menu utama ini juga dapat ditutup.

Adapun tampilan menu utama adalah sebagai berikut:

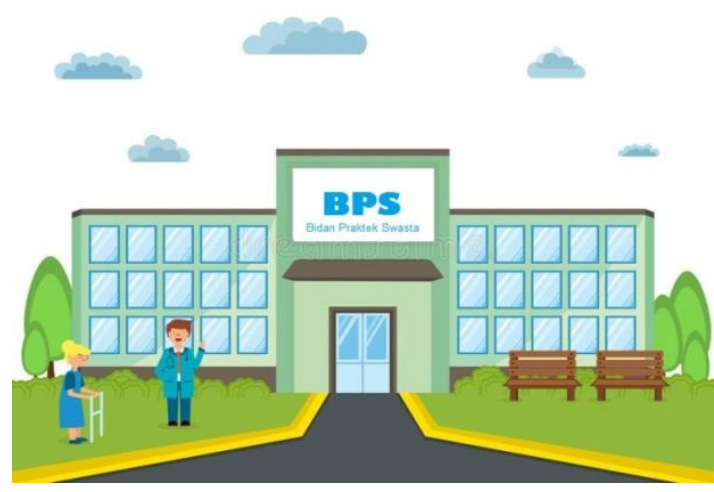

Gambar 14. Tampilan Menu Utama

Adapun contoh dari sub-menu adalah sebagai berikut:

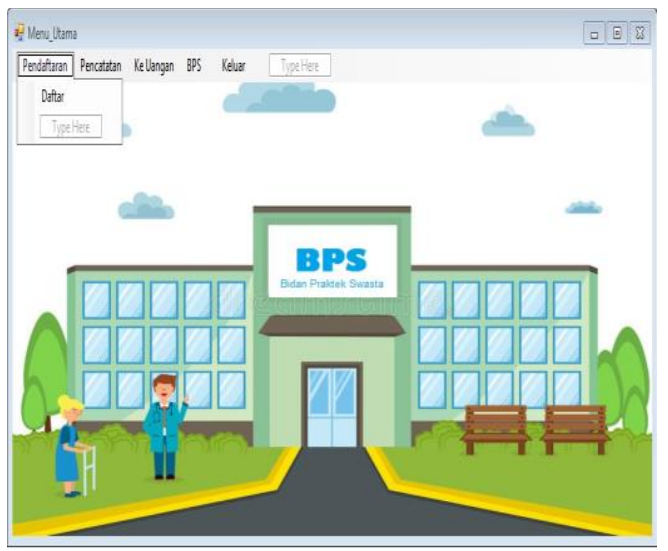

Gambar 15. Tampilan sub-menu Utama

3. Tampilan Menu Pendaftaran

Tampilan menu pendaftaran memiliki $s u b$ menu yaitu daftar.

Adapun tampilan menu daftar adalah sebagai berikut:

a. Tampilan sub-menu daftar

$S u b$-menu ini digunakan untuk input data pendaftaran yang dimana didalam sub-menu daftar terdapat button tambah, edit, hapus, reset dan kembali. Button tambah digunakan 
menambahkan data daftar. Button edit digunakan untuk merubah isi data yang sudah ditambahkan. Button hapus digunakan untuk menghapus data yang sudah dimasukan kedalam database. Button reset digunakan untuk mengulang memasukan data daftar kedalam sistem. Button kembali digunakan untuk kembali ke menu utama.

Adapun tampilan menu pendaftaran adalah sebagai berikut:

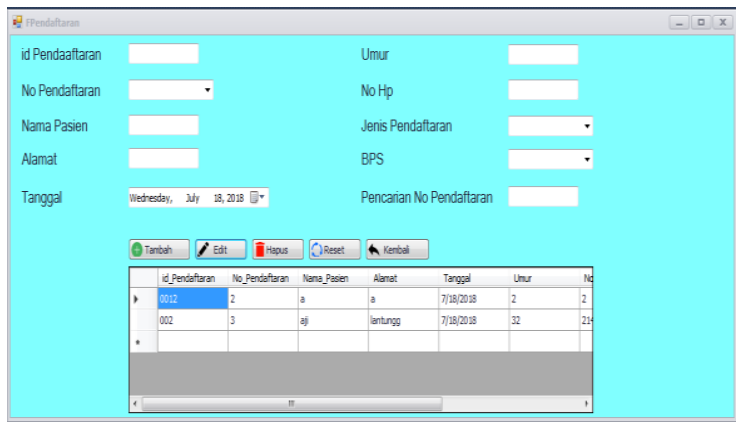

Gambar 16. Tampilan Menu Pendaftaran

4. Tampilan Menu Pencatatan

Tampilan menu pencatatan memiliki submenu yaitu alkom, ibu hamil, imunisasi, kb, obat, pasien, rujukan tamu.

Adapun tampilan sub-menu tersebut adalah sebagai berikut:

a. Tampilan sub-menu alkom

Sub-menu ini digunakan untuk input data alkom yang dimana didalam sub-menu alkom terdapat button tambah, edit, hapus, reset dan kembali. Button tambah digunakan untuk menambahkan data alkom. Button edit digunakan untuk merubah isi data yang sudah ditambahkan. Button hapus digunakan untuk menghapus data yang sudah dimasukan kedalam database. Button reset digunakan untuk mengulang memasukan data alkom kedalam sistem. Button kembali digunakan untuk kembali ke menu utama.

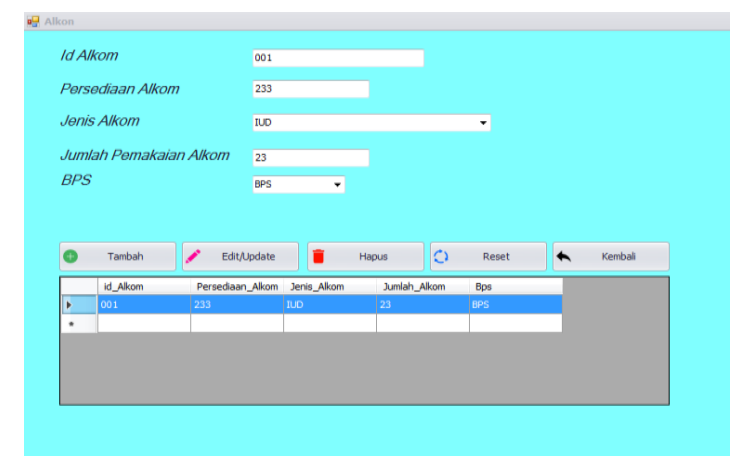

Gambar 17 Tampilan Menu Alkom

b. Tampilan Menu Imunisasi

Sub-menu ini digunakan untuk input data imunisasi yang dimana didalam sub-menu imunisasi terdapat button tambah, edit, hapus, reset dan kembali. Button tambah digunakan untuk menambahkan data imunisasi. Button edit digunakan untuk merubah isi data yang sudah ditambahkan. Button hapus digunakan untuk menghapus data yang sudah dimasukan kedalam database. Button reset digunakan untuk mengulang memasukan data imunisasi kedalam sistem. Button kembali digunakan untuk kembali ke menu utama.

Adapun sub-menu data imunisasi adalah sebagai berikut:

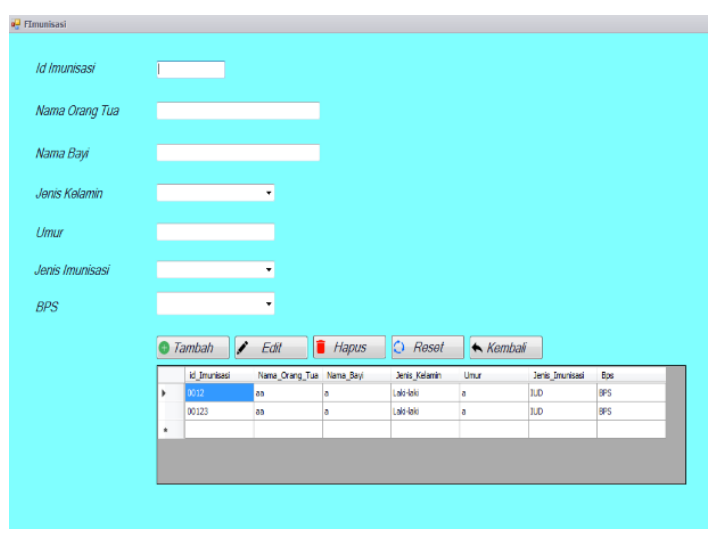

\section{Gambar 18 Tampilan Menu Imunisasi}

c. Tampilan Menu $\mathrm{Kb}$

Sub-menu ini digunakan untuk input data $\mathrm{kb}$ yang dimana didalam $s u b$-menu kb terdapat button tambah, edit, hapus, reset dan kembali. Button tambah digunakan untuk menambahkan data kb. Button edit digunakan untuk merubah isi data yang sudah ditambahkan. Button hapus digunakan untuk menghapus data yang sudah dimasukan kedalam database. Button reset digunakan untuk mengulang memasukan data imunisasi kedalam sistem. Button kembali digunakan untuk kembali ke menu utama. Adapun tampilan dari menu kb adalahsebagai berikut:

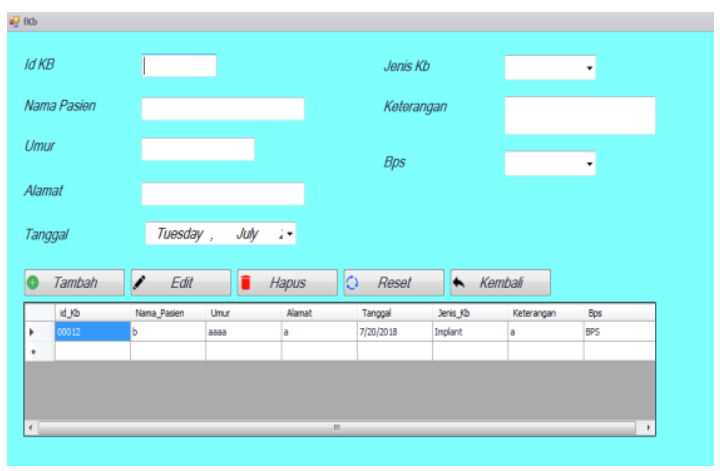

Gambar 19. Tampilan Menu Kb

d. Tampilan Menu Obat 
Sub-menu ini digunakan untuk input data obat yang dimana didalam sub-menu obat terdapat button tambah, edit, hapus, reset dan kembali. Button tambah digunakan untuk menambahkan data obat. Button edit digunakan untuk merubah isi data yang sudah ditambahkan. Button hapus digunakan untuk menghapus data yang sudah dimasukan kedalam database. Button reset digunakan untuk mengulang memasukan data obat kedalam sistem. Button kembali digunakan untuk kembali ke menu utama.

Adapun tampilan dari menu obat adalah sebagai berikut:

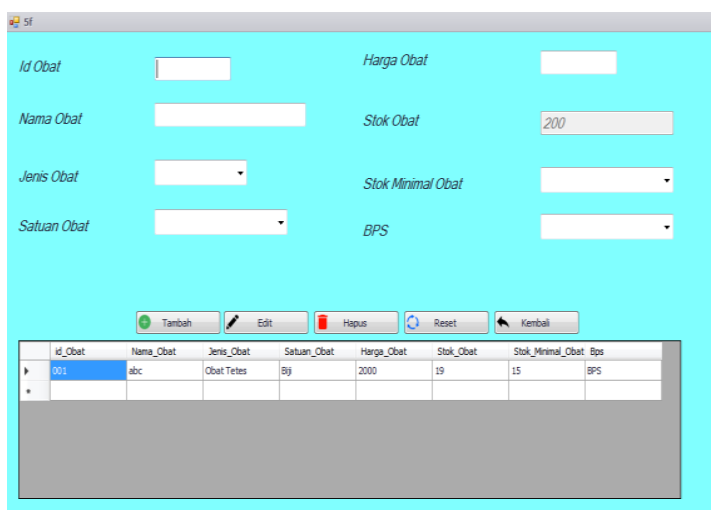

\section{Gambar 20 Tampilan Menu Obat}

e. Tampilan Menu Rujukan

Sub-menu ini digunakan untuk input data rujukan yang dimana didalam sub-menu rujukan terdapat button tambah, edit, hapus, reset

dan kembali. Button tambah digunakan untuk menambahkan data pasien yang dirujuk. Button edit digunakan untuk merubah isi data yang sudah ditambahkan. Button hapus digunakan untuk menghapus data yang sudah dimasukan kedalam database. Button reset digunakan untuk mengulang memasukan data rujukan kedalam sistem. Button kembali digunakan untuk kembali ke menu utama.

Adapun tampilan menu rujukan adalah sebagai berikut:

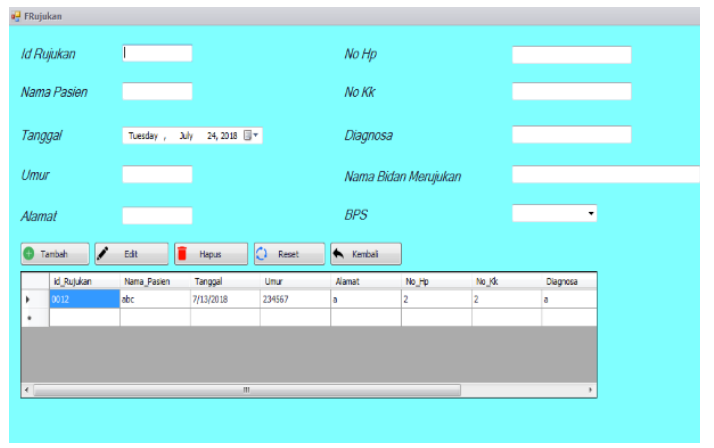

Gambar 21. Tampilan Menu Rujukan
1. Tampilan Menu Laporan Pemasukan Keuangan Sub- menu ini merupakan sub-menu dari ke uangan yaitu dengan cara mencetak hasil dari pemasukan ke uangan yang di lakukan admin sebagai laporan bulanan untuk mempermudah admin dalam proses pencarian data.

Adapun tampilan menu pemasukan ke uangan adalah sebagai berikut:

\begin{tabular}{|c|c|c|c|}
\hline \multicolumn{4}{|c|}{$\begin{array}{c}\text { Bidan Peraktek Swasta } \\
\text { BPS }\end{array}$} \\
\hline id Pemasukan & 001 & Jumlan obat & 0 \\
\hline Nama obat & a & Harga Obat & ${ }^{2}$ \\
\hline Nama Imunisasi & $=$ & Hargas Imunisas & 2 \\
\hline Jenis Imunisssi & a & Haraga Alkom & ${ }^{2}$ \\
\hline Nama Alkom & a & Harag Terael & 2 \\
\hline Jenis Alkom & a & & \\
\hline Nama Terapi & a & & \\
\hline Jenis Terapi & a & & \\
\hline Tangast & 7/18/2018 & & \\
\hline Jumlan Pemasukan & 8 & & \\
\hline Bes & BPS & & \\
\hline
\end{tabular}

\section{Gambar 22.Tampilan Menu Laporan Pemasukan.}

\section{Pengujian Sistem}

Dalam pengujian ini dilakukan dengan menggunakan whitebok yaitu pengecekan pengecekan input apakah sudah benar sesesuai dengan harapan yang diinginkan. Metode whitebok merupakan metode pengujian yang menggunakan control dari perancangan untuk melalakukan proses uji coba dan mengetahui apakah sistem yang telah dibuat berhasil atau tidak.

Adapun proses pengujian sistem adalah sebagai berikut: 
Tabel 8. Proses Pengujian

\begin{tabular}{|c|c|c|c|c|}
\hline $\begin{array}{l}\mathrm{N} \\
\mathrm{O}\end{array}$ & Pengujian & Tujuan & Indikator & $\begin{array}{l}\text { Hasil } \\
\text { Pengujian }\end{array}$ \\
\hline 1 & $\begin{array}{l}\text { Koneksi } \\
\text { database }\end{array}$ & $\begin{array}{l}\text { Menjalankan } \\
\text { program }\end{array}$ & $\begin{array}{l}\text { Akses } \\
\text { dapat } \\
\text { dilakukan }\end{array}$ & $\begin{array}{l}\text { Pengujian } \\
\text { berhasil }\end{array}$ \\
\hline 2 & Login & $\begin{array}{l}\text { Mengecek } \\
\text { proses klik } \\
\text { menu login }\end{array}$ & $\begin{array}{l}\text { Masuk ke } \\
\text { tampilan } \\
\text { utama }\end{array}$ & $\begin{array}{l}\text { Pengujian } \\
\text { berhasil }\end{array}$ \\
\hline & $\begin{array}{l}\text { Pengopras } \\
\text { ian menu }\end{array}$ & $\begin{array}{l}\text { Mengecek } \\
\text { pengoprasian } \\
\text { menu beserta } \\
\text { sub menu } \\
\text { dengan } \\
\text { melakukan } \\
\text { inputan } \\
\text { terhadap } \\
\text { masing- } \\
\text { masing menu }\end{array}$ & $\begin{array}{l}\text { Tampilan } \\
\text { halaman } \\
\text { menu dan } \\
\text { sub menu } \\
\text { dilakukan } \\
\text { oleh } \\
\text { admin }\end{array}$ & $\begin{array}{l}\text { Pengujian } \\
\text { berhasil }\end{array}$ \\
\hline 4 & $\begin{array}{l}\text { Pengopras } \\
\text { ian menu }\end{array}$ & $\begin{array}{l}\text { Mencetak } \\
\text { laporan } \\
\text { berdasarkan } \\
\text { masukan } \\
\text { yang } \\
\text { dijadikan } \\
\text { kunci utama }\end{array}$ & $\begin{array}{l}\text { Tampilan } \\
\text { data } \\
\text { berupa } p d f\end{array}$ & $\begin{array}{l}\text { Pengujian } \\
\text { berhasil }\end{array}$ \\
\hline 5 & Logout & $\begin{array}{l}\text { Mengecek } \\
\text { proses keluar } \\
\text { sistem }\end{array}$ & $\begin{array}{l}\text { Keluar } \\
\text { dari } \\
\text { sistem }\end{array}$ & $\begin{array}{l}\text { Pengujian } \\
\text { berhasil }\end{array}$ \\
\hline
\end{tabular}

\section{PENUTUP}

\section{Kesimpulan}

Adapun kesimpulan yang didapatkan dari proses penelitian adalah sebagai berikut:

1. Pembuatan sistem informasi pencatatan dan laporan pada BPS ini menghasilkan suatu sistem informasi berbasis desktop dengan menggunakan vb.net untuk mempermudah dalam proses pencatatan pada BPS "Fitri Alatif".

2. Pembuatan sistem informasi BPS ini untuk mempermudah dalam proses memasukan data dengan secara otomatis karna menggunakan vb.net berbasis dekstop dan lebih mudah dalam proses mencetak data.

Pembuatan sistem informasi dalam bentuk laporan pada BPS untuk mempermudah membuat laporan menggunakan crystal report.

\section{REFERENSI}

1. Sutabri, Tata. 2012. Konsep Sistem Informasi. Yogyakarta: Andi Offset.

2. Dani Anggoro, Nofiyani. 2016. "ANALISA DAN RANCANG BANGUN SISTEM INFORMASI PELAYANAN BIDAN PRAKTEK SWASTA (STUDI KASUS BIDAN SILVIANA)" Jurnal Ilmiah Teknologi Informasi Terapan, Volume III, No 1, 15 ISSN : 2407 - 3911, hal: 1

3. Winarno, Wahyu Wing. 2006. Sistem Informasi Manajemen, Edisi ke enam. Yogyakarta: UPP STIM YKPN

4. Sommerville, Ian. 2011. Software Engineering (Rekayasa Perangkat Lunak). Jakarta: Erlangga. 